\title{
Green Marketing Practices and Issues: A Comparative Study of Selected Firms in Indonesia and Philippines
}

\author{
Maria Agustini (D) ${ }^{a}$, Anna Baloran (iD) ${ }^{b}$, April Bagano (iD) ${ }^{b}$, Ana Tan (iD) \\ Sentot Athanasius ${ }^{c}{ }^{c}$, and Berta Retnawati ${ }^{c}{ }^{c}$ \\ aUnika Soegijapranata, Semarang, Indonesia; 'bniversity of San Carlos, Cebu, Philippines; 'Universitas \\ Katolik Soegijapranata, Semarang, Indonesia
}

\begin{abstract}
Green marketing has become increasingly important to promote environmental sustainability, and studies on the subject have been conducted, especially in developed countries. Therefore, this research evaluates the green marketing practices and issues of the selected firms in emerging countries. Information from in-depth interviews with three firms each from Indonesian and Philippines, which produce green products were explored and analyzed. The findings showed that the practices were slightly different due to variations in the level of knowledge, and the lack of consumers' awareness and acceptance of the product was the main issue faced by firms.
\end{abstract}

\section{KEYWORDS}

Green marketing mix; green marketing practices; green product; Indonesia;

Philippines

\section{Introduction}

Green marketing refers to activities directed at minimizing negative impacts on the environment (Weisstein, Asgari, \& Siew, 2014). These practices have not been embraced universally (Cekanavicius, Bazyte, \& Dicmonaite, 2014) and are applied by only a few businesses in the world. However, the importance of supporting environmental sustainability has been considerably higher as marketing has contributed significantly to the development and manufacture of green products (Dangelico \& Vocalelli, 2017). According to Dangelico and Vocalelli, green products that are intended to reduce the impacts of industrial activities will be useless for environmental sustenance except they are spread widely and enabled by the market. Also, marketing is essential to foster consumerism and through communication programs, benefits from using these products and building customers' awareness concerning environmental sustainability can be achieved (Kalafatis, Pollard, East, \& Tsogas, 1999).

Firms practicing green marketing face more complexities than those operating via the conventional type as the process is required to be comprehensive and business-wide (Marketing-schools.org, 2016). This, therefore, means that it is insufficient to advertise the green properties of a product or the company if the manufacture and distribution disregard environmental concerns. Failing to do so 
can cause the firm to be labeled as green-washer and this can be harmful to the company's credibility, as well as customers' trust, making them shift their purchases to more trustworthy competitors (Ottman \& Mallen, 2014).

Specific issues in the practice of green marketing are related to the demand, costs, and consumer perception (Gurau \& Ranchhod, 2005). Demand for these products is relatively low due to a lack of consumers' awareness causing a majority of the firms offering green products to struggle for market shares (Marketing-schools.org, 2016). Also, many companies view these practices as costly, both in monetary and non-monetary terms, and potentially reduce the profits because the firms have to shoulder the extra burdens of environmental expenses on all their activities (Ottman \& Mallen, 2014; Solaiman, Osman, \& Halim, 2015). Consequently, green products are usually sold at higher prices than conventional products, making it more costly for consumers to purchase them. Green products are also perceived to fail to meet some consumers' expectations (Solaiman et al., 2015; Sudhalakshmi \& Chinnadorai, 2014; Yazdanifard \& Mercy, 2011) because they usually have unglamorous images (Gurau \& Ranchhod, 2005), are boring and uninteresting in appearance.

Studies on green marketing have focused on consumers and involve topics like factors influencing the purchase of these products (Kumar \& Ghodeswar, 2015; Lin \& Chen, 2016), consumer (Naderi \& Steenburg, 2018; Thakur, 2016; Yan \& Yazdanifard, 2014), and purchase behaviors (Delafrooz, Taleghani, \& Nouri, 2014; Govender \& Govender, 2016; Gupta \& Ogden, 2009), as well as the intention to procure the products (Kalafatis et al., 1999). However, studies on businesses are not as massive as those focusing on consumers, and these researches are performed more frequently in developed countries, such as Europe and the US (Abdelzaher \& Newburry, 2016; Fraj, Martinez, \& Matute, 2011), and only a few have explored green marketing and the relation to businesses in emerging countries (Chouhary \& Gokarn, 2013; Durmaz \& Yasar, 2016). Therefore, this study addresses the green marketing practices on firms in developing countries for several reasons.

First, markets for green products are mainly in developed countries, such as Western Europe, North America, and Australia (Gurau \& Ranchhod, 2005), and the practicing firms there are tremendous in number (Puopolo, Teti, \& Milani, 2015). The contrary is the case in emerging countries where the markets and firms for green products are still infants, thus, inciting interests to study the phenomena in these countries.

Second, the demand for green products has increased during the last few decades due to tremendous growth in environmental concerns and awareness, especially in developed countries. (Kumar \& Ghodeswar, 2015; Naderi \& Steenburg, 2018) However, this demand has been largely unsatisfied, thereby, creating opportunities for firms in emerging countries to serve (Kumar \& Ghodeswar, 2015). Thus, studying green marketing practices of firms in developing countries can contribute to understanding the efforts to use these 
capabilities as leverage and enable them to contend with established competitors. According to Fraj et al. (2011), green marketing can be a strategy to enhance the profitability of a firm through performance optimization and cost reduction.

Third, Cekanavicius, Bazyte, and Dicmonaite (2014) stated that the application of green business depends on national specifics which means that marketing practices will also possibly vary between countries. Therefore, this study seeks to understand the practices and issues in emerging countries to understand the role of national specifics in green marketing.

Meanwhile, this research focuses on selected firms in Indonesia and the Philippines that produce green products and aims at understanding the practices and issues faced by these companies during marketing. The scope of this study is the $4 \mathrm{Ps}$ of the green marketing mix and the findings contribute to enhancing the knowledge of emerging countries where green marketing practices are limited and also, to be the reference for implementation in these countries.

The next section discusses green marketing concepts followed by the description, as well as the methodology used to collect and analyze the data. A summary of the results and the research implications are to conclude the paper.

\section{Literature review}

Green marketing involves associated activities connected to the environment and is defined as marketing and movements directed toward the creation of products that are environmentally responsible and safe (Kotler \& Keller, 2008), along with strategies that use ecological issues for marketing (McDaniel \& Rylander, 1993). Here, a company's marketing activities are linked with the environment through product adaptation or modification, production process, packaging, promotion strategies, as well as an increasing awareness of compliance marketing amongst industries (Yazdanifard \& Mercy, 2011).

Green marketing requires a holistic approach (Marketing-schools.org, 2016) which means that a company cannot simply highlight and consider the product aspect to be compliant with green practices. However, real concern and commitment toward the environment on multiple levels must be exhibited, such as during production processes or engagement, else, the company would be labeled as a green-washer.

Consequently, these activities modify the elements of the marketing mix into the green product, price, promotion, and place (Yazdanifard \& Mercy, 2011), and each entity is discussed below.

\section{Green product}

Green products are environmentally friendly and the definition signifies that ecological purposes should be the basis of design (Sudhalakshmi \& Chinnadorai, 2014). More practically, these products are created using nontoxic 
ingredients by following environment-friendly procedures (Gurau \& Ranchhod, 2005). Also, eco-labels certify that the products are green- compliant (Yazdanifard \& Mercy, 2011) or eco-friendly (Gurau \& Ranchhod, 2005).

Kumar and Ghodeswar (2015) emphasized that greening a product should cover the whole lifecycle from design, material procurement, manufacture, storage, distribution, usage, and even post-usage activities. Environmental sustainability, and not solely profit, must be considered while developing and commercializing these products. For instance, a company should be concerned with reducing excessive packaging by using recyclable materials since this process is a major source of environmental waste.

However, the majority of firms specializing in green products were observed to be unsuccessful in their businesses (Chahal, Dangwal, \& Raina, 2014). Since many of these products fail to meet customers' expectations (Solaiman et al., 2015; Sudhalakshmi \& Chinnadorai, 2014), the market shares are unable to increase significantly.

\section{Green price}

This is considered as one of the most difficult aspects of green marketing (Sudhalakshmi \& Chinnadorai, 2014) and refers to the consideration of the environment while designating product prices (Yazdanifard \& Mercy, 2011). Expenses incurred from company activities required to modify the production process, such as packaging and disposal for environmental compliance will also affect the price.

The prices of green products are typically higher than the conventional equivalents and this reflects the environmental and social expenses added to the costs. Studies have shown that this is the major barrier to the purchase of green products by consumers (Weisstein et al., 2014), and making the prices reasonable, affordable, and competitive is a challenge (Sudhalakshmi \& Chinnadorai, 2014; Yazdanifard \& Mercy, 2011) as higher values can discourage potential consumers and reduce the competitiveness. Therefore, Weisstein et al. (2014) suggested to consider the consumers' degree of greenness in pricing, as the more eco-friendly the consumers are, the greater their willingness to pay higher for these products. The perception that consumers would pay more for green products can also be the basis for pricing (Solaiman et al., 2015). In the future, price is expected to be the indicator of socially and environmentally responsible businesses (Li \& Tang, 2010), and to also educate consumers to realize that paying a little more for a green product is worthwhile.

\section{Green promotion}

Green promotion refers to activities that educate and change consumers' views on green products (Yazdanifard \& Mercy, 2011), and is expected to 
communicate substantive environmental information that contains meaningful relations to the company's activities (Solaiman et al., 2015). Although loyal customers can be acquired through this (Yazdanifard \& Mercy, 2011), the company must not overclaim so as not to be perceived as green-washers, which may lead consumers to ignore the promotion, boycott products, or to complain to regulators.

Significant differences do not exist between green and other forms of promotion (Li \& Tang, 2010) as both have similar approaches and bases. Accordingly, the aims of green advertising are also analogous to those of the conventional form, which are information concerning the company and product, persuading consumers to switch to a green brand, and reminding customers where and how to purchase the products.

\section{Green distribution}

Green distribution involves presenting the products to the right consumers, particularly those that are environmentally aware (Yazdanifard \& Mercy, 2011), and also providing guarantees of the product's "ecological nature". According to Li and Tang (2010), the eco-performance of a product is affected by the geographical relationship between the points of manufacture, purchase, and use during the distribution process.

The green distribution includes internal and external aspects (Sudhalakshmi \& Chinnadorai, 2014). Internally, the awareness and observation of the company managers and employees toward the environmental issues existent in the processes are required. Externally, the places for offering the products and services must have the least harm to the environment. Green distribution can also be viewed from a physical and an economic perspective (Li \& Tang, 2010), where it relates to managing logistics that simplify transportation emissions and aim at reducing the carbon footprint (Solaiman et al., 2015) physically. From the economic perspective, it is concerned with developing and managing a channel structure that supports the physical distribution of goods and is also capable of handling the exchange of information, money, and product ownership. Both perspectives have implications for the green agenda, thus, developing a credible distribution strategy goes beyond improving the practicalities of fuel efficiency, shipping packaging, and the noise produced by depots.

\section{Methods}

The study addressed the firms located in Central Java situated in Indonesia, and Cebu in the Philippines, which are manufacturers of green products and were selected based on the researchers' rational judgment. This approach was used for selection as official sources containing information on green firms are nonexistent, while the judgment was executed by referring to the 
definition and compatibility of the green products manufactured by the companies in the two countries. Here, green products were defined as environmentally friendly commodities that use natural or nontoxic ingredients, and as a result, lessen negative impacts on the environment during the production process (Solaiman et al., 2015). The analyzed firms in both countries manufactured similar products and the comparison was for experimental purposes only. Meanwhile, the process had undergone several changes due to the availability, accessibility, and willingness for the companies in both countries to participate and ended with comparable but not entirely identical products. Subsequently, the Indonesian companies produced herbal drinks, natural cosmetics, and natural colored clothings, while the Philippine firms manufactured natural medicines using herbal tonics, natural cosmetics, and home furnishings.

Furthermore, face-to-face in-depth interviews were performed for the Indonesian and Philippine companies respectively, to collect information from the owner or manager of the selected firms. An interview guide was prepared to ensure an adequate comparison of the gathered information and the questions covered practices in the four elements of the marketing mix, as well as issues faced by the management while marketing their products. The firms were contacted to confirm their willingness to participate in the study using formal letters which were followed up through the phone and on receiving the agreement, interview appointments were set up.

The interviews were conducted at the agreed place and time with the interviewees at either the inside or outside of the company facility and each took approximately 60-75 minutes. Based on the availability of time after the interview, a company tour followed or was set for another occasion.

Data from the interviews were analyzed by employing a qualitative approach which is particularly useful for in-depth studies of small numbers of persons or organizations (Gurau \& Ranchhod, 2005), while interview transcriptions were used to systematically identify special message characteristics using selection criteria (Berg, 2004). More specifically, the analysis was to identify practices and issues in green marketing by using criteria from the marketing mix elements which are product, price, promotion, and place. In addition to these, challenges and opportunities experienced by the selected firms in marketing their product were employed.

\section{Results}

\section{Brief profile of the selected firms}

In line with the purpose of this study, the profiles of the selected firms in Indonesia were expected to be comparable to those from the companies in the Philippines. The selected firms varied in size and duration of the business and 
Table 1. Profiles of the selected firms.

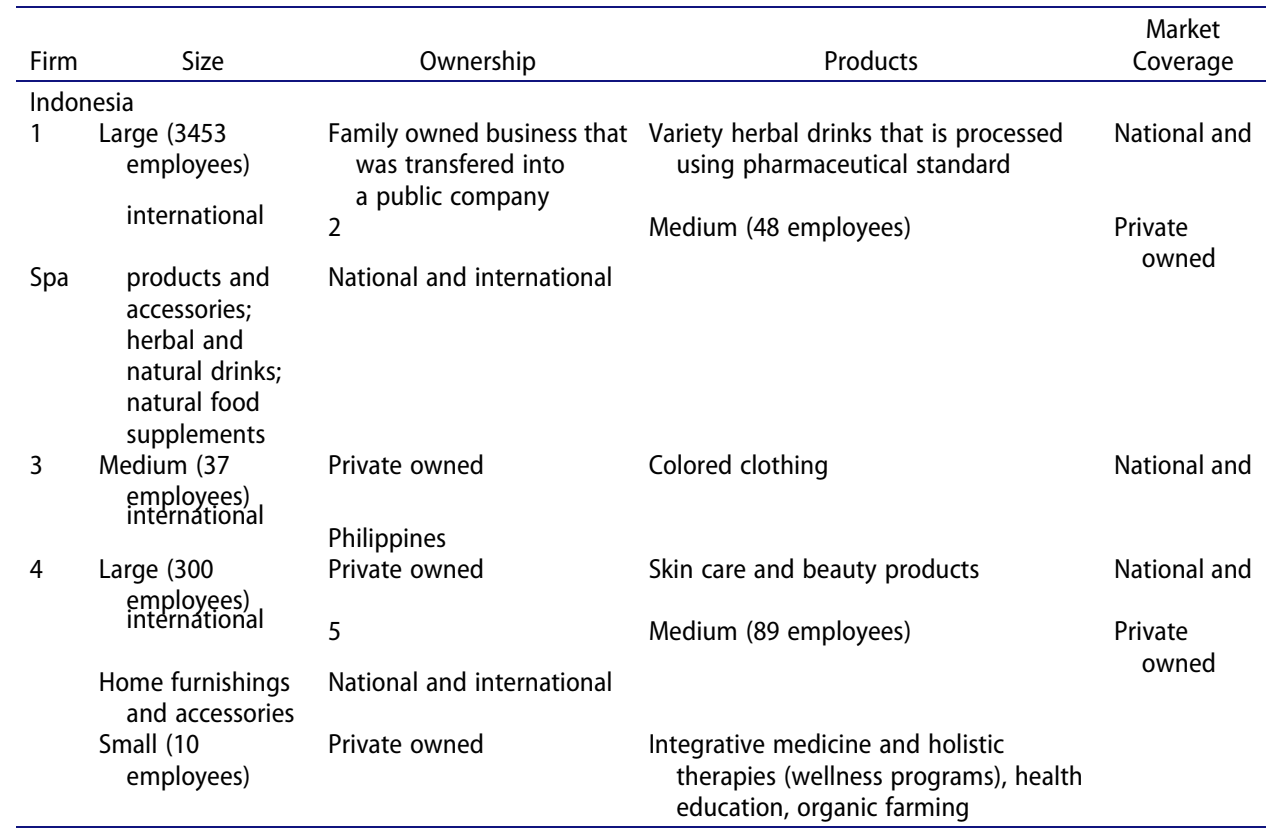

they were either small, medium, or large firms and had been in the business from 7 to over 60 years. Furthermore, the businesses were all privately owned by an individual or a family, and the daily operations of the firm were handled by the owner through the assumption of the topmost manager position. The family business also involved other members such as the spouse and children in the management. Consequently, the Indonesian business was managed by a third-generation family member, while the founder still controlled the Philippine counterpart and had delegated some responsibilities to his children.

These firms manufactured green products that are frequently used natural ingredients that are available locally or in areas where these materials can be sufficiently supplied. The companies have established cooperation concerning plant cultivation with farmers and suppliers of materials with standardized quality. With these green products, therefore, the firms entered the international markets in some developed countries, such as the USA and Western Europe. Table 1 presents their profiles briefly.

\section{The green initiatives of the selected firms}

Meanwhile, the selected firms had similar concepts in starting their businesses and neither realized at the beginning that their business ideas were so-called green initiatives.

The Indonesian companies were unsure that their willingness to manufacture through their usual methods was capable of being called a green initiative 
as the commitment from the onset was to create viable products. For instance, the firm producing natural cosmetics had started the business by commercializing the traditional style that was formerly employed by the local women of using available natural materials for beautification. The valuable opportunity for the production of natural cosmetics was realized by the founder, then, cooperation with farmers for supply was established for the particular assurance that the materials were sufficient in the required quantity and quality.

Although the firm producing the herbal drinks had a similar process historically, long experience in the business had engendered a high commitment of the management toward the environment. The principle that all items taken from mother earth must be returned to it was constantly emphasized to the employees at all levels and this had been the drive for the company activities which were always directed to prevent environmental damage. For this reason, the firm has invested millions of rupiahs for building and developing their waste management facilities so that all disposals are safe and are reproduced into useful products.

The use of leaves, stems, and roots of particular plants to color clothes was viewed as a way to differentiate products. However, the founder was unaware that this method contributed to greening the environment by reducing the chemical wastes that resulted from the coloring process commonly used by firms that produced similar attires.

The initiative for starting to produce green home furnishing materials by the Philippine firm was a spontaneous idea that arrived while the founders were cleaning a forested area. This region surrounded the production facility and these individuals collected agro-forest debris, such as fallen leaves, shrubs, and twigs. Rather than burning the collected items as was the usual practice in provinces, they experimented on the wastes as raw material for their products and turned the natural objects into utilitarian works of art.

Also, the founder of the Philippine's natural cosmetics firm formerly prepared soap at home using coconut oil, papaya, and carrot. Then, the initiative to develop other skincare products such as moisturizing and bleaching creams, sunblock, clarifying toner, carrot lotion, etc., and commercialize them was acquired.

A similar idea was the trigger for the founder of the natural healing firm when the realization of the need for holistic advocacy in health and wellness by promoting lifestyles that prioritize organic and natural products in the country was attained. Then, the wellness farm was established in collaboration with twenty farmers where a wide range of vegetables and herbs around the health and spa facilities were grown. 


\section{The marketing practices of the selected firms}

\section{Green product}

The selected firms from both countries claimed to manufacture green products and the reasons were the use of natural materials, avoidance of chemical additives, and the generation of fewer pollutants. Meanwhile, the Indonesian firms were not initially aware that their product was categorized as green due to the management's lack of knowledge. Workshops and training which they had participated in, as well as information from the local government, imparted this knowledge and brought them to finally understand the green product and business.

The management of the Filipino firms seemingly had more knowledge and had recognized that their products were green and behaved accordingly from the outset. Also, the products of the natural furnishing firm were well known locally and internationally and greenness was emphasized in every promotion and activity. Recognizing the potencies, the products and processes were patented to prevent them from being copied by any other manufacturer or supplier. As a result, the firm gained multiple awards for the "green" practices and was titled as one of the ecopreneurs in the Philippines. Although environmental factors were not explicitly considered by the firm during product design, some company policies were integrated by reinforcing the green initiatives, such as the use of as little packaging material as possible to avoid waste.

Furthermore, the founder of the natural healing products saw a big opportunity in the market for the need for natural treatment processes and so, the naturality and attributes of the products and services were sold. The Filipino natural cosmetics firm ensured that the ingredients and processes used were environmentally friendly and safe, and recyclable or biodegradable packaging materials that do not result in environmental pollution were used. Also, the firm assured that they were compliant with all legal requirements especially of the environment and that all the production procedures were a zero-waste process.

\section{Green pricing}

The majority of the selected firms stated that green elements were not considered in their pricing which was set with the use of regular cost-based methods. This was done by adding a margin on the basic production costs which did not contain environmental expenses. According to the Indonesian firms, higher prices of green products compared to similar conventional commodities were because of the production processes and not the environmental costs. For instance, a piece of naturally colored cloth was rinsed fifteen times compared to only three times for the conventional product. This caused the natural material to be set at a higher price because more time was required for the production of that particular color compared to the regular one. Also, the higher price of the Indonesian natural cosmetics was due to the longer 
hygienic procedure required for preparing the materials before further processing, rather than to environmental-related costs.

Conversely, the Filipino natural cosmetics firm added environmental expenses to its pricing to ensure the firm's ecological programs were sustainable. This was the only selected firm that used green pricing while the other Filipino companies practiced regular pricing methods based on costs plus fixed profit margin which was determined according to the products.

\section{Green promotion}

The Indonesian firms did not explicitly promote their products as green, but rather highlighted the natural characteristics, such as the color-processed cloth and cosmetic ingredients. For this company, the highlight was to educate consumers with low awareness and acceptance of natural or green products, indicating that the firms recognized that the markets were still limited. Therefore, media such as magazines, radios, company websites, and trade shows that do not specifically target green consumers were used. Also, the colored clothing firm used the company's website to specifically educate consumers about their products.

The promotional activities by the Indonesian herbal drink firm highlighted the function of the products, which were intended to be positioned as a middle-up product. The firm used environmental issues in some of the promotions to show concern for the environment. In one of the adverts, it presented the damage on a large river that previously was an important source of clean water for the local people but was becoming blackened due to the irresponsible behavior of individuals by throwing rubbish and wastes into the river. In the end, the ad showed a message with concern toward recovering the river.

The Filipino firms give more emphasis on green practices in their promotional activities. For instance, the purpose of each promotion activity of the natural home furnishing firm was to educate and converse with the consumers about green-mindedness. This was done through a feature in books and magazines after being multi-awarded green ecopreneurs, as well as through advocacy. The natural cosmetics firm had a similar purpose and each promotional activity was to create awareness for the product and the brand. Meanwhile, the firm definitely considered the environment in product promotion by highlighting the natural benefits and encouraging awareness of environmental protection. The firm organized tree planting every year to ensure that it restored what was due to the environment, and relied on testimonials from the guests for the promotion of the products and services. Then, the testimonial videos were uploaded to the firm's website to attract local and international consumers while print publications, such as educational materials, as well as books written by the founder, were other methods of promotion. 


\section{Green distribution}

The selected firms did not consider environmental issues in choosing methods of product distribution.

The Indonesian companies did not specifically address the green consumers but focused on the conventional buyers instead, and specialty stores were the choice for the colored clothing and cosmetics firms to sell their products in the local market. The first has a personal outlet in the facility area to offer people stop-shopping where the consumers were able to buy, as well as be taught how to draw and wax cloth, learn the history of the traditional material, watch the production process, and discuss on a related topic in a provided space. Conversely, the herbal drinks firm which had a company website did not sell online but distributed a variety of products to many retail stores. The websites were mostly to give information about the firms and products which were exported to some countries in Europe, the USA, Africa, and Asia.

Furthermore, the Philippine firms used similar methods of distribution by using retail and specialty stores to cater to the local market and conducted exports to serve some international countries such as Europe, America, Africa, and Asia. The home furnishing firm sold the products through luxury retail and specialty stores, such as international store chains, hotels, restaurants, and government offices, and the distribution was done directly by the company. Besides retail outlets, the cosmetic firm entered online trading to cater to consumers that wished to buy through this platform. Likewise, the healing firm used online methods to serve international consumers and the organic products were sold particularly based on order, requests were accepted from guests at the office Farmers' Market in the city, and the company traded each Sunday at the Town Center.

Table 2 presents practices according to each element of green marketing mix and country.

\section{The issues faced by the selected firms}

Each firm had faced different issues but had no negative experiences and although these issues were either related to green or business matters, the latter was more dominant than the first. Also, the firms observed opportunities in marketing their products as the potential was high and demand in the future was to increase considerably.

The Indonesian firms faced challenges related to product, regulation, and consumers, while the cloth firm experienced struggles during promotion since a lack of acceptance was still existent.

For the herbal drinks firm, compliance with the regulations was the main challenge to maintain the green proper. This is a label awarded by the Indonesian government for any manufacturing company that complies with environmental regulations. Consequently, firms are evaluated regularly and 
Table 2. Marketing practices of the selected firms.

\begin{tabular}{|c|c|c|}
\hline & Indonesia & Philippines \\
\hline \multicolumn{3}{|l|}{ Product } \\
\hline & $\begin{array}{l}\text { Claim the product as green was based on several } \\
\text { criteria covering natural ingredients/materials, } \\
\text { no chemical additives, safe wastes, and less } \\
\text { wastes. } \\
\text { Support the claim with green certification such } \\
\text { as eco label and green proper. }\end{array}$ & $\begin{array}{l}\text { Claim on green product was based on natural } \\
\text { ingredients; biodegradable material for } \\
\text { packaging, no plastics usage. } \\
\text { Support the claim either with certification } \\
\text { (FDA, Halal, ISO) or with no green certification }\end{array}$ \\
\hline Price & $\begin{array}{l}\text { Practice non-green pricing: cost- based method, } \\
\text { which covers costs of production and fixed } \\
\text { mark-up, and no environmental expenses } \\
\text { added to the product price. }\end{array}$ & $\begin{array}{l}\text { Practice green pricing: cost-based method, which } \\
\text { covers costs of production, fixed mark-up, and } \\
\text { environmental costs to the product price. }\end{array}$ \\
\hline Promotion & $\begin{array}{l}\text { Use combination of several activities and tools for } \\
\text { promoting the product: ads on newspapers } \\
\text { and radio; trade shows, national and } \\
\text { international exhibitions; seminars; sales } \\
\text { promotion girls; and online promotion via } \\
\text { company website. }\end{array}$ & $\begin{array}{l}\text { Use combination of several activities and tools for } \\
\text { promoting the product: ads on newspapers } \\
\text { and radio; trade shows, national and } \\
\text { international exhibitions; seminars; sales } \\
\text { promotion girls; and online promotion via } \\
\text { company website. }\end{array}$ \\
\hline Place & $\begin{array}{l}\text { Use conventional ways in distributing the product } \\
\text { locally and nationally through firm outlet, retail } \\
\text { stores, and specialty stores. } \\
\text { Sell the product abroad by exporting it } \\
\text { indirectly }\end{array}$ & $\begin{array}{l}\text { Use conventional ways through retail stores and } \\
\text { specialty stores for product distribution. } \\
\text { Direct and indirect exports were to sell product } \\
\text { abroad. }\end{array}$ \\
\hline
\end{tabular}

awarded a proper status ranging from black and green which denote total noncompliance and total compliance, to red and blue in-between. The firm believed that a good company image could be built by complying with the regulations.

Furthermore, the consumers were the challenge for the cosmetics firm where only a few people trusted the benefits of natural products. Customer education was the answer arrived at by the company and qualified sales promotion girls were employed to give information and train consumers.

The Filipino natural home furnishing firm claimed that it had never dealt with negative issues. This was despite the minimal concern of consumers about the environment and welfare of the society, as well as a lack of support from the Local Government Units (LGU) to encourage consumers to purchase from the local market and educate them on green consumerism. The biggest challenge in marketing the products was the green certification which is not yet available in the Philippines and is costly and unaffordable to obtain from Europe or the United States.

The challenge of the Philippine cosmetics firm was the fierce competition caused by the open trade between the ASEAN Countries where imported products have imposed a threat on the local commodities. Consequently, the firm conducted research to discover the type of product wanted by the target consumers and to also strengthen the marketing focus as one of the cosmetic innovators in the Philippines specialized in using endemic natural resources that were only found locally.

An issue faced by the natural healing firm was the absence of certification due to a lack of funds, thereby, causing the company's success to be dependent 
Table 3. Issues faced by the selected firms.

\begin{tabular}{ll}
\hline Indonesia & Demand in the future was to increase considerably \\
- Lompliance with the green certification is a challenge \\
- Limited knowledge of the management on green product \\
- Limited green procurement availability \\
- Lompliance to the regulation \\
- Thilippines \\
- There is an increasing demand \\
- Have certified by the international standards \\
- Lack of consumer awareness \\
- Lack of government support \\
- Have no green or other certifications due to lack of funds \\
- Onliffen competition because of penetration of new players to the market \\
- Strive to provide customers the latest products innovative
\end{tabular}

on the testimonies of the guests. The capability to serve guests or patients was limited because only the founder was able to personally attend and lecture the wellness program.

Table 3 presents marketing issues faced by the selected firms according to country.

\section{Discussion}

The founders of the selected firms started their business with a green initiative. This refers to an initiative where the main objective is to develop greener economies and a sustainable future (ILO, 2018) by offsetting greenhouse gas emissions produced by human activities such as industrial production processes. However, they were unaware and had conducted their businesses, as usual, meaning strategic actions were implemented to facilitate the growth and operation of the business in non-green markets.

The products were exported to other countries, particularly developed ones, due to the presence of opportunities in these areas. This was possible because the consumers there recognize the products as green and were able to purchase them at cheaper prices. This is congruent with the study by Gurau and Ranchhod (2005) where imported green products from the emerging countries were declared to be cheaper for the markets in developed countries, and this has created opportunities for firms in emerging countries to serve them.

Although the firms were not fully aware of their initiative, the founders claimed to produce green products and the reasons given were that these commodities were in line with the criteria mentioned in previous studies, such as the use of natural materials, absence of chemical additives, and the generation of fewer pollutants (Cekanavicius, Bazyte, \& Dicmonaite, 2014; Gurau \& Ranchhod, 2005; Solaiman et al., 2015). 
While the firms did not claim to establish green pricing, their methods can be viewed as the impact of modification in the production process that must be considered during the manufacture of the green product (Kumar \& Ghodeswar, 2015; Solaiman et al., 2015). In the case of the selected firms, the impact was indirect where the elevated price was observed to result from higher costs occurring from the production process which is different from conventional commodities due to the natural materials being used. Higher prices are likely not to hinder consumers from purchasing green products as they will continue to buy at higher prices so far the benefits are worthwhile compared to the gains of choosing a conventional product (Kumar \& Ghodeswar, 2015). However, similar prices of green and conventional products can help to boost sales (Ottman \& Mallen, 2014).

Promotion and distribution are not yet totally classified as green because though natural features are utilized, the selected firms have not positioned their products as such. Consumers buy the commodities because of the natural characteristics and an exception to this is the firm producing natural home furnishing that consciously exposed the greenness of the products during promotion and addressed those consumers seeking organic items.

Generally, it can be stated that the selected firms have not fully practiced green marketing but conventional strategies for their product possibly due to relatively limited demand (Gurau \& Ranchhod, 2005). For example, the clothing company produced naturally and synthetically colored attires to sustain the business as the demand for the latter is relatively higher than for natural equivalent. Also, this condition may be linked to consumer perception as green products are perceived to possess unglamorous, dull, and boring appearances which make them unattractive for consumers (Lin \& Chen, 2016). Therefore, it is unworthy for some customers to pay higher prices for dull-looking natural clothing.

In general, the issues faced by the selected firms were related to either green or business issues but the latter was more dominant than the former. The green concerns were mainly related to the lack of consumers' awareness and acceptance of the products resulting in some of the selected firms exerting efforts into customer education. Furthermore, the business issue was mainly about the stiff competition arising from the increase in the number of new players entering the markets. The threat comes from the local, as well as foreign businesses from other ASEAN countries that can enter freely as a result of economic integration between the countries.

\section{Conclusion}

Given the lack of studies on the application of green marketing to firms in emerging countries, this study investigated the practices and issues experienced by selected Indonesian and Philippine companies that manufacture 
green products. Assuming the strategic market acts uniformly, the practices can be used to predict the conditions for green products faced by the selected firms in particular.

The samples used in the study were limited to a total of six firms, however, a comparative analysis on a small number of firms which is a similar approach by previous researches (Kumar \& Ghodeswar, 2015) was employed. Consequently, two countries were compared to observe for the country specifics taken into account while differentiating between the practices and issues. The results showed that the country did not distinguish between these factors the practices and issues and that the firms in both countries had slightly different practices and issues while marketing their green products.

The factor differentiating the practices was the management's knowledge about green marketing and this was observed to be comparably less in the Indonesian firms than in the Philippines. Consequently, the Indonesians accordingly practiced less green marketing and although they produced green products, it had not reflected in their pricing, promotion, and distribution. On the other hand, the firms in the Philippines possessed higher awareness, and promoted the greenness of their products, addressed those consumers that sought organic commodities, and one even applied green pricing. This is congruent with the research by Yasir and Majid (2017) where knowledge was stated to be an enabler for enhancing particular economic activities.

Also, similar issues were faced by the firms in both countries, and the most dominant was related to the market condition indicated by a lack of consumer awareness and acceptance of the green product. However, the firms were optimistic that the market potency would grow in the future and, thus, continued investing in consumer education and related their promotional programs toward it. Green certification is considered beneficial for the firms to tap into the markets, but the lack of funds has hindered them from obtaining it. Therefore, similar market conditions homogenized marketing practices and eliminated the country-specific role.

In the future, more samples should be used, firms should be compared based on size and governmental roles. Therefore, this study showed that the larger-sized selected firms tended to perform greener marketing practices. Also, government supports were encouraged to assume roles in providing affordable certification and enabling conditions for practicing green procurements and leveraging consumerism.

Green marketing has not been fully understood by firms in emerging countries. Thus, these findings can give insight into green marketing practices and issues in such countries. Practically, the results can be used as references for firms in developing countries that wish to apply green marketing to create strategies that suit the condition of the businesses in those regions. 
Furthermore, the function of the government in enabling green marketing practices was noted and this can be the reference for the creation of programs that support green firms.

As the study cannot be generalized because of the qualitative approach used, more researches should be conducted with a higher number of samples in additional emerging countries to confirm the occurrence of similarities amongst the countries. Therefore, the practices in the context of developing countries would be made more apparent.

\section{Acknowledgments}

The authors are grateful to the Indonesian General Directorate of the Ministry of Research and Technology Higher Education who awarded the grant for this research under the contract no. 00867/B.7.2/LPPM08/2018 from which this manuscript is generated.

High appreciation to the research team in San Carlos University in Cebu, Philippines who have become the wonderful partner for us. Thank for the supports, contributions, and good coordination during the research process so the research can successfully finish in time.

Thank and appreciation to the owners or management of the selected firms for their participation in the research and permission for allowing us to observe their practices. Their participation is highly important for the research.

\section{Disclosure statement}

No potential conflict of interest was reported by the author(s).

\section{ORCID}

Maria Agustini (D) http://orcid.org/0000-0002-3330-249X

Anna Baloran (D) http://orcid.org/0000-0001-5801-2934

April Bagano (iD http://orcid.org/0000-0002-7590-1562

Ana Tan (D) http://orcid.org/0000-0001-5965-6678

Sentot Athanasius (ID http://orcid.org/0000-0002-6721-8157

Berta Retnawati (D) http://orcid.org/0000-0002-4264-8791

\section{References}

Abdelzaher, D., \& Newburry, W. (2016). Do green policies build green reputations? Journal of Global Responsibility, 7(2), 226-246. doi:10.1108/JGR-05-2016-0012

Berg, B. L. (2004). Qualitative research methods for the social sciences (5th ed.). Boston, MA: Pearson Education, Inc.

Cekanavicius, L., Bazyte, R., \& Dicmonaite, A. (2014). Green business: Challenges and practices. Ekonomika, 93(1), 74-88. doi:10.15388/Ekon.2014.0.3021

Chahal, H., Dangwal, R., \& Raina, S. (2014). Antecedents and consequences of strategic green marketing orientation. Journal of Global Responsibility, 5(2), 338-362. doi:10.1108/JGR-092013-0012 
Chouhary, A., \& Gokarn, S. (2013, July). Green marketing: A means for sustainable development. Journal of Arts, Science \& Commerce, IV-3(3), 26-32.

Dangelico, R. M., \& Vocalelli, D. (2017). “Green marketing”: An analysis of definitions, strategy steps, and tools through a systematic review of the literature. Journal of Cleaner Production, 165, 1263-1279. doi:10.1016/j.jclepro.2017.07.184

Delafrooz, N., Taleghani, M., \& Nouri, B. (2014). Effect of green marketing on consumer purchase behavior. QScience Connect, 5, 1-9.

Durmaz, Y., \& Yasar, H. V. (2016, June). Business and management studies. Green Marketing and Benefits to Business, 2(2), 64-71.

Fraj, E., Martinez, E., \& Matute, J. (2011, July). Green marketing strategy and the firm's performance: The moderating role of environmental culture. Journal of Strategic Marketing, 19(4), 339-355. doi:10.1080/0965254X.2011.581382

Govender, J. P., \& Govender, T. L. (2016). The influence of green marketing on consumer purchase behavior. Environmental Economics, 7(2), 77-85. doi:10.21511/ee.07(2).2016.8

Gupta, S., \& Ogden, D. T. (2009). To buy or not to buy? A social dilemma perspective on green buying. Journal of Consumer Marketing, 26(6), 376-391. doi:10.1108/07363760910988201

Gurau, C., \& Ranchhod, A. (2005). International green marketing: A comparative study of British and Romanian firms. International Marketing Review, 22(5), 547-561. doi:10.1108/ 02651330510624381

ILO. (2018). The green innitiative-ILO. Author. Retrieved from http://www.ilo.org $>$ centenar y>lang-en

Kalafatis, S. P., Pollard, M., East, R., \& Tsogas, M. H. (1999). Green marketing and Ajzen's theory of planned behaviour: A cross-market examination. Journal of Consumer Marketing, 16(5), 441-460. doi:10.1108/07363769910289550

Kotler, P., \& Keller, K. L. (2008). Marketing management (13th ed.). Essex: Pearson Education, Inc.

Kumar, P., \& Ghodeswar, B. M. (2015). Factors affecting consumers' green product purchase decisions. Marketing Intelligence \& Planning, 33(3), 330-347. doi:10.1108/MIP-03-20140068

Li, S., \& Tang, Z. (2010). Understanding green marketing with marketing mix-A case study on the body shop. Gavle: University of Gavle.

Lin, C.-J., \& Chen, H.-Y. (2016). User expectancies for green products: A case study on the internal customers of a social enterprise. Social Enterprise Journal, 13(3), 281-301. doi:10.1108/SEJ-02-2016-0004

Marketing-schools.org. (2016, November 10). Green marketing. Author. Retrieved from http:// www.marketing-schools.org/types-of-marketing/green-marketing.html

McDaniel, S. W., \& Rylander, D. H. (1993). Strategic green marketing. Journal of Consumer Marketing, 10(3), 4-10.

Naderi, I., \& Steenburg, E. V. (2018). Me first, then the environment: Young millennials as green consumers. Young Consumers, 19(3), 280-295. doi:10.1108/YC-08-2017-00722

Ottman, J., \& Mallen, D. G. (2014, January 14). Five green marketing strategies to earn consumers trust. GreenBiz. Retrieved from https://www.greenbiz.com/blog/2014/01/14/fivestrategies-avoid-taint-greenwash-your-business

Puopolo, G. W., Teti, E., \& Milani, V. (2015). Does the market reward for going green? Journal of Management Development, 34(6), 729-742. doi:10.1108/JMD-03-2014-0027

Solaiman, M., Osman, A., \& Halim, M. S. (2015, February). Green marketing: A marketing mix point of view. International Journal of Business and Technopreneurship, 5(1), 87-98.

Sudhalakshmi, K., \& Chinnadorai, K. (2014). Green marketing mix - A social responsibility of manufacturing companies. Global Journal of Commerce and Management Perspective, 3(4), 109-112. 
Thakur, M. (2016). Impact of green marketing on consumer behavior in modern world - A case study with reference to retail and consumer durables. International Journal of HIT Transaction on ECCN, 2(2A), 77-84.

Weisstein, F. L., Asgari, M., \& Siew, S.-W. (2014). Price presentation effects on green purchase intentions. Journal of Product \& Brand Management, 23(3), 230-239. doi:10.1108/JPBM-062013-0324

Yan, Y., \& Yazdanifard, R. (2014). The concept of green marketing and green product development on consumer buying approach. Global Journal of Commerce and Management Perspective, 3(2), 33-38.

Yasir, M., \& Majid, A. (2017). Impact of knowledge management enablers on knowledge sharing: Is trust a missing link in smes of emerging economies? World Journal of Entrepreneurship, Management and Sustainable Development, 13(1), 16-33. doi:10.1108/ WJEMSD-02-2016-0010

Yazdanifard, R., \& Mercy, I. E. (2011). The impact of green marketing on customer satisfaction and environmental safety (Vol. 5, pp. 637). International Conference on Computer Communication and Management, Proc. of CSIT, Singapore: IACSIT Press. 